\title{
INNOVATIVE APPROACHES TO FUTURE TEACHERS' TRAINING IN HIGHER EDUCATION INSTITUTIONS
}

Savchenko Vitalii, Senior Lecturer at Technology Education Department, Pavlo Tychyna Uman State Pedagogical University.

ORCID: 0000-0001-9140-1683

E-mail: vvsat24@ukr.net

Pavliuk Victoriia, PhD in Pedagogical Sciences, Associate Professor of Foreign Languages Department, Pavlo Tychyna Uman State Pedagogical University.

ORCID: 0000-0002-9612-2218

E-mail: vika.pavlyuk83@gmail.com

The paper describes the results of a research study on the problem of future teachers' training based on the analysis of scientific literature and law regulated documents. The analysis revealed two main innovative approaches (regulatory-directed and subjectively intended) to future foreign languages teachers' training in institutions of higher education in Ukraine that appear in the new changes in higher education in particular. The authors found out that mentioned innovative approaches should be evaluated as the most powerful and positive in their results: structural and semantic upgrade of future teachers' training in higher education institutions (three-level model of training, additional profiles training, competence-oriented content training) and provide its further resource update (personnel, informational, technological, etc.).

Keywords: modernization, innovative approaches, education, training process, future teachers, higher education institutions.

\section{ІННОВАЦЙНІ ПІДХОДИ ДО ПЦДГОТОВКИ МАЙБУТНІХ УЧИТЕЛІВ У ЗАКЛАДАХ ВИЩОЇ ОСВІТИ}

Савченко Віталій, старший викладач кафедри технологічної освіти, Уманський державний педагогічний університет імені Павла Тичини.

ORCID: 0000-0001-9140-1683

E-mail: vvsat24@ukr.net

Павлюк Вікторія, кандидат педагогічних наук, доцент кафедри іноземних мов, Уманський державний педагогічний університет імені Павла Тичини.

ORCID: 0000-0002-9612-2218

E-mail: vika.pavlyuk83@gmail.com

Після приєднання до Болонського процесу, зміни у підходах до викладання у закладах вищоі освіти стосуються, насамперед, тих акцентів, щчо переходять від процесу до результатів навчання, зміни ролі вчителя, зосередження на інтенсивності програм, методах контролю та оцінки результатів знань студентів. Мета статті полягає у виявленні інноваційних підходів до підготовки майбутніх учителів у закладах вищої освіти. Результати дослідження полягають у тому, щсо автори статті на основі аналізу наукової літератури та нормативних документів різного рівня, розглядаючи модернізацію вищої педагогічної освіти як перманентний процес, виокремили й обтрунтували інноваџійні підходи (нормативно-спрямовані, суб'єктивно- 


\begin{abstract}
спрямовані) до професійної підготовки майбутніх учителів, які проявляються в нових змінах до організачії процесу професійної підготовки в закладах вищої освіти $і$ змістовному його наповненні. 3'ясовано, що нормативно-спрямовані підходи здійснюються в прочесі модернізаџї $i$ стандартизачії педагогічної освіти Украӥни $i$ мають відповідне нормативно-правове забезпечення. Відповідно до мети статті було визначено такі інноваційні підходи до підготовки майбутніх учителів у закладах вищої освіти Украӥни, які знаходяться на стадії інституалізації (багаторівневість, багатопрофільність, неперервність професійної підготовки, ї̈ компетентнісноорієнтований характер); окремі - на стадії ініціації $i$ реалізації (варіативність, практикоорієнтованість підготовки); локально або суб'єктно-спрямовані підходи містять сукупність чинників, обумовлених особливостями розвитку певного регіону краӥни, традиціями науково-педагогічної школи закладу вищої освіти або ініиійовані та реалізовані в окремому закладі вищої освіти (індивідуалізація підготовки, нова фундаменталізація, аксіологізація, психологізація).

Ключові слова: модернізаџія, інновачійні підходи, освіта, процес підготовки, майбутні вчителі, заклади вищої освіти.
\end{abstract}

The beginning of the $21^{\text {st }}$ century is notable for Ukraine's accession to the Bologna Process, which radically changed the situation in the system of higher education and marked a new stage of its development. There have been made significant steps that have contributed to Ukraine's joining to the European educational space and also laid the foundation for the entire modernization of educational system and future teachers' training according to international standards. The introduction of the Bologna principles, which are the factor of our country's European integration and means of facilitating citizens' access to qualified education, requires fundamental reform of the whole paradigm of higher education, in particular, updating teaching methods, assessment and training quality assurance. After joining the Bologna process, changes in approaches to teaching relate primarily to accents shifting from process to learning outcomes, the changing role of a teacher, focus on learning and dynamics (intensity) of programs, methods of monitoring and assessment [2, p. 154].

There are tense debates of domestic and foreign scientists of V. Bezliudna., A. Verkhola, A. Vlasenko, V. Zahviazynskyi, V. Ziabkin, V. Kazakov, O. Kovalenko, V. Kolomiets, S. Sysoieva, M. Stepko and others about: "who is a teacher in the modern world?" and about innovative changes of a teacher's professional activity in conditions of European integration. Therefore, in the article we want to focus on the innovative changes in future teachers' training (FTT), considering their development on different stages.

The article is aimed at defining innovative approaches to future teachers' training in institutions of higher education of Ukraine.

Considering the modernization of higher education as a permanent educational process, we characterize innovative approaches to future teachers' training in higher education institutions (HEI), which were found out at the present stage of its development [1]. On the basis of summarizing factual material on the research topic, it was found out that the current stage of FTT in a pedagogical university is characterized by such innovative approaches as:

- regulatory directed - made in the process of modernization and standardization of teacher's education in Ukraine and have the appropriate regulatory support. Some changes are being made at the stage of institutionalization (multi-level, versatility, lifelong learning, its competence-oriented nature); some - at the stage of initiation and implementation (variability, practice-oriented training);

- locally or subject-focused - include a combination of factors caused by 
development peculiarities of a certain country's region, traditions of scientific and university's "pedagogical school" or initiated and implemented in a particular university (individualization of training, new fundamentalization, aksiologization).

We have systematized and generalized innovative approaches to future teachers' training in higher education institutions (Fig. 1).

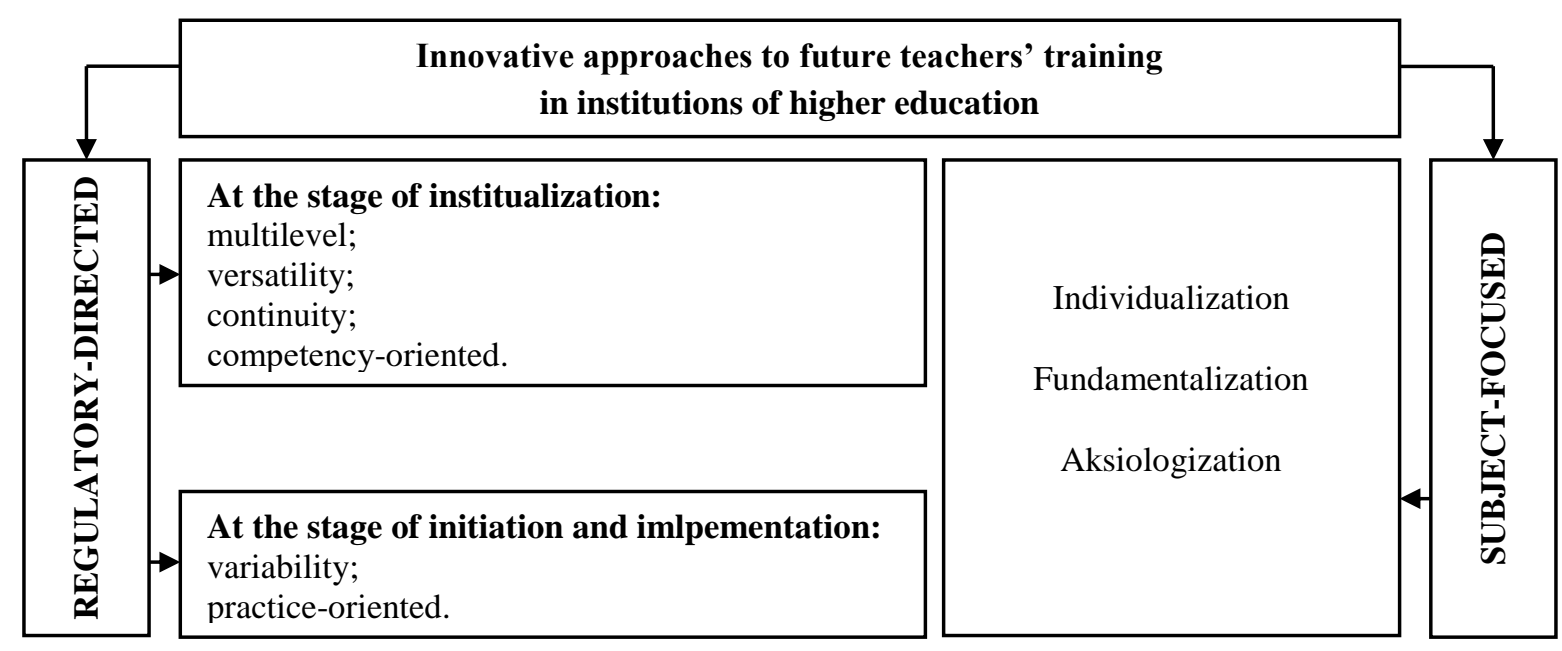

Fig. 1. Innovative approaches to future teachers' training

Regulatory-oriented approaches occur at new changes to the organization of the vocational training process in a pedagogical university and its meaningful content. At the stage of institutionalization, characterized by fixing new norms of activity in teacher's training in HEI, such changes of future teachers' training are defined: multi-level, versatility, continuity, competence-oriented nature of the training. In HEI these changes occur as follows:

1. Professional training in pedagogical university has multi-level structure. In Ukraine, levels of university vocational training coincide with established levels of higher education training periods within which a future specialist learns the basic educational program of higher education and at the end receives a state diploma. Levels differ in educational programs' volumes in credits, consequently, the degree that graduates get after training.

Ukraine's accession to the Bologna process has necessitated significant changes in the content and organization of training of highly competent specialists in accordance with the new strategy of higher education in creating two-level educational model "Bachelor-master". The most important landmarks of this developmental strategy are: the transition to a multilevel system of future professionals' training; modular training and "credit modular" form of control to allow scientific methodological support of students. Level education as a flexible variable system provides future teachers of foreign languages the opportunity to choose their own path of teacher's education for the realization of which they are responsible.

2. Step organization of future foreign languages teachers' training also supports the idea of a teacher's professional development continuity (lifelong learning), creating real conditions for an individual's return to the systematic professional education after/or in the course of practical professional activity.

Continuity training of students has some unity and integrity, which include "formal" 
and "informal" aspects. Nowadays, with the help of point-rating system, it is available to take into account professional experience of students, the results of their prior learning, foreign languages department students' learning outcomes on basis of additional education programs, the results of implementing their own creative projects of social and educational targeting, results in a particular workplace. Continuous training of future teachers is also provided by gradual accumulation of knowledge, consistency in the development of specific competencies with the help of psycho-pedagogical subjects content "synchronization" (with didactic units, clusters of learned competencies, etc.).

3. Versatility of FTT in HEI is provided by basic and additional profiles. Each student is required to determine the basic profile of training and fulfil its requirements. In addition to the basic training, students can choose an additional training profile, but it is not compulsory.

4. One of the approaches that characterize training of future teachers at the present stage of its development is competence approach [5].

Competence approach provides a modern high school with wide potential to improve the training quality of future specialists. European educational community, according to ideas of I. Piankovska, actively considers and implements opportunities of competence approach to teachers' training. This is evidenced by numerous scientific researches and regulatory framework of some European countries. Implementation of competence approach to the standardization of the educational field content is, according to the majority of foreign experts' views, one of the main moments of efficient educational standards' foundation. In the context of a humanistic paradigm competence conducts the role of motivational and unity student's orientations as a future teacher [6].

In this regard, the standards of higher education are developed as standards of competency model with credit system usage that are able to develop characteristic ideas of system-activity approach to education and multi-level training in Ukrainian higher education; development of invariant and variant parts of modules to student's choice, aimed at students' mastering the content according to educational needs; in a student's choice of individual educational route that best meets personal, educational and professional needs.

Obviously, according to the competence approach, changes in the content of vocational education cause corresponding changes in preparation of foreign languages teachers training.

Firstly, there is a change of linear to nonlinear forms of transition to modular curriculum in order to provide a choice of individual educational trajectories, designing individual educational routes. Secondly, understanding of future teachers' training at the university appears not only as a development process of norms, patterns and rules of professional and educational activities, but as a process of future teachers' subjective experience, which reflects the degree of their valuable acceptance of these norms, samples and rules of professional educational activities. Thirdly, there is a changing nature of interaction between a teacher and a student - from a formal role in structural and interpersonal, focused primarily on the organization of a student's independent work. The role of teacher's positions change, he ceases to perform the main source of information and becomes a coach, academic advisor, tutor, designer of teaching materials and so on. Fourthly, there are new requirements for selecting technology for future teachers' training at the university. Professionally-oriented technologies (contextual, designed, training, simulative, and reflexive) contribute to the formation of students' personality traits for future significant 
professional and educational activities, as well as knowledge and skills that ensure quality performance of their duties.

Competence-oriented understanding of professional training in a pedagogical university places new demands on its resources support - informational, methodological, personnel, etc.

The quality of future specialists' vocational training largely depends on the formation of its general cultural, socio-cultural and communicative competence. The versatile and professional development of individual teachers, including teachers of foreign languages, provides a high level of socio-cultural knowledge and skills to use them in the foreign language intercultural communication.

Thus, competence formation and development of FTT in practice is the cumulative result of factors and conditions of the whole university educational process. Appropriate educational environment of a university and department, updated organizational forms of its construction teaches students to be independent and self-organized.

Spreading ideas of competence approach to future teachers' training in universities and their attachment to the regulatory level in competency-based standards requires further integration into the practice of future teachers' training [7].

At the stage of initiation and implementation, which is characterized by the emergence and spread of new activities' standards in teachers' training in HEIs, such changes appear in FTT as variability and practice orientation.

Since 2005/2006 academic year in all higher pedagogical establishments of Ukraine, European Credit Transfer System is being provided and therefore, training of future foreign language teachers in a pedagogical university in terms of subject-subject organization of teachers and students is made in accordance with European system of credits' accumulation and transference. Domestic Provisional Regulations on the educational process organization according to the credit-module training system notes that "credit-modular system of educational process is a model of the educational process, which is based on modular technology training and classification of educational units (test credits)" [4].

According to conclusions of V. Odintsova, A. Roshhupkina and R. Kurbanov, the use of credit-module system helps intensify the learning process, specify and systematize learning material acquisition, promotes the most efficient and effective implementation of independent work, providing high quality level education of competitive specialists for the future of Ukraine's economy. Meanwhile, a modular organization leads to the reorganization of the whole learning process, necessitates the development of new and modernization of existing training methods, techniques and forms of educational work organization with students. Special features of credit-modular training include logical structuring of the educational material content and feeding it into modules; create modular programs and sequencing of study modules; objective assessment system that enables operational control of the educational process and its adjustment; variability studies (each student develop his own line of study); maximum adaptation of the learning process to the individual characteristics of each student [3].

Designated innovations in university practice are as follows:

1. Variability of students' vocational training in a pedagogical university provides students with the choice of their way of acquiring educational programs and is realized by means of new approaches to training organization (modules); content design of disciplines 
and practices (educational professional tasks and corresponding objectives of different types and complexity levels), assessing students' achievement (cumulative, rating, complex, etc.), development of educational and methodical complex, which provides scientific, methodological and organizational practical support.

2. Strengthening of practice oriented training of future teachers in a pedagogical university is not only increasing the number of practice hours and their diversity, but changing all educational process components in high school objectives, content, forms and methods of learning its results.

The results of scientific research can be concluded that practice orientation of future teachers of foreign languages training in HEI is reflected in:

- increasing of practical training period length;

- the creation of new in-depth professional-oriented types of practices: educational, industrial practice in summer camps. Different practices provide immersion of future teachers in a professional environment that allows them to observe, study and generalize the best pedagogical practices; the opportunity to match their perceptions of professional and educational activities, the profession as a whole with real requirements of educational reality;

- the development of practice-oriented training materials and tasks within disciplines;

- $\quad$ increasing number of hours for students' independent work;

- usage of modern professional-oriented training technologies within disciplines (contextual learning, project learning, dynamic learning, etc.) that provide developing contexts of preparation, variety of practical tasks in the process of solving in which students work on real problems "taken from life" - analyse them, participate in discussions with their teachers, seeking information for the selection and decision-making, critically comprehend the results of solving practical problems and take responsibility for the choice of this or that decision.

Outlined above regulatory and targeted approaches to students' vocational training in HEI is the result of modernization reforms held in the framework of Ukraine's education, which were found on the basis of regulatory documents' analysis. Local or subject-focused approaches of students' training in HEI are set by specific factors particular to a region of a country; traditions of scientific-pedagogical institute of a definite higher educational establishment; individual of a supervisor or a tutor of the university.

There are certain conditions for subject-directed approaches in the university or they are initiated and implemented by supervisors, deans or university tutors. These changes include individualization, new fundamentalization and aksiologization of training.

Consequently, individualization of FTT in a pedagogical university is expressed in its targeting, creating conducive conditions to getting by each student a unique experience of solving personal and professional problems, and promotes interests and needs of each student. Individual approach which is implemented by a tutor, contributes to the disclosure of personal potential of each student; takes into account individual characteristics of classes' organization, practices, individual and extracurricular activities; helps in selecting the engagement strategy with each student according to these individual characteristics. Individualized environments allows students to show their personal attitude to the discussed teaching reality phenomena, to express themselves in a freely creative way, find personal meaning in the test questions, use 
different means of expressing their feelings, thoughts and needs in the process of solving educational, professional or communication tasks, etc.

New fundamentalization of FTT is associated with current needs of students' general cultural development and their entry into the universal knowledge that have interdisciplinary character and is the basis for the formation of latitude and alternative views, different ways of thinking and activity, expansion of erudition and outlook which further help them in solving complex professional and educational tasks.

In the term of "fundamentalization" such scientists as S. Semerikov and O. Teplytskyi [9], understand the significant increase in the quality of education and educational level of people by a corresponding change in the content of the taught disciplines and methodology of the learning process.

Change in understanding of students' vocational training fundamentalization in a pedagogical university is a shift from substantive and methodological training (professional training depth) in the direction of psychological and educational training (humanitarian versatile training).

New fundamentalization of future teachers' vocational training at the university changes focus on the development of their capacity for activity, work in all its forms, including its professional creative part. This does not mean that the role of knowledge in any way is diminished, appealing as means of personal future teachers' development, the formation of their subjective experience, hence the rejection of training content understanding the content as a set of comprehensive (encyclopaedic) information for applied skills' development benefit, the formation of which occurs on bases of current scientific knowledge.

Aksiologization of students' training in a pedagogical university is caused by increased attention to moral values of modern teachers' education, which sets the appropriate direction to vocational training changes. Aksiologization of vocational training is due to the necessity of valuable formation of teachers' competence basics, because it is available in a student's system of values, it determines his professional conduct, relations in the organization and choice of accepted decisions.

According to the aim of the article, such innovative approaches to future teachers' training in higher education institutions of Ukraine were defined: regulatory-directed approaches at the stage of institualization (multi-level, versatility, continuity) and at the stage of initiation and imlpementation (variability, practice-oriented); subject-focused approaches (individualization, fundamentalization, aksiologization). So, it is true to argue that the innovative approaches mentioned above should be evaluated as the most powerful and positive in their results: structural and semantic upgrade of future teachers' training in higher education institutions (three-level model of training, additional profiles training, competenceoriented content training) and provide its further resource update (personnel, informational, technological, etc.).

\section{СПИСОК ВИКОРИСТАНИХ ДЖЕРЕЛ}

1. Безлюдна В. Професійна підготовка майбутніх учителів іноземних мов у системі вищої освіти. Педагогічні науки: теорія, історія, інноваційні технологї. 2016. № 4. С. 178-185.

2. Вища освіта України і Болонський процес: навч. посіб. / за ред. В. Г. Кременя. Тернопіль: Навчальна книга. Богдан, 2004. 384 с.

3. Одинцова В. М., Рощупкина О. А. Особливості навчання іноземних студентів в умовах кредитномодульної системи. Запорожский медицинский журнал. 2012. № 4. С. 74-76. 
4. Про проведення педагогічного експерименту з кредитно-модульної системи організації навчального процесу: Наказ Міністерства освіти і науки України від 23.01.2004 p. № 48. URL: https://zakon.rada.gov.ua/rada/show/v0048290-04\#Text (дата звернення: 18.12.2020).

5. Курлянд 3. Н. Психолого-педагогічні умови формування професійно-педагогічної компетентності майбутнього вчителя. Наука і освіта. 2008. № 8-9. С. 171-176.

6. П'янковська I. В. Визначення ключових компетентностей майбутніх учителів у країнах Європи. Вища освіта України. Тематичний випуск «Вища освіта України у контексті інтеграції до європейського освітнього простору». 2008. Т. 1. Вип. 8. С. 384-391.

7. Семеріков С. О. Фундаменталізація навчання інформаційних дисциплін у вищій школі: монографія / наук. ред.: акад. АПН України, д. пед. н., проф. М. І. Жалдак. Кривий Ріг: Мінерал; К.: НПУ ім. М. П. Драгоманова, 2009. 340 с.

8. Степко М. Ф. Компетентнісний підхід: його сутність. Що є прийнятним, а що проблемним для вищої освіти України. Вища освіта України: теор. та науково-метод. часопис. К., 2009. С. 43-52.

9. Теплицький О. І. Об'єктно-орієнтоване моделювання в системі фундаменталізації підготовки майбутнього вчителя інформатики. Збірник наукових пращь. Педагогічні науки. Херсон: Вид-во ХДУ, 2008. Вип. 50, ч. 2. С. 285-288.

\section{REFERENCES}

1. Bezliudna, V. (2016). Profesiina pidhotovka maibutnikh uchyteliv inozemnykh mov u systemi vyshchoi osvity. Pedahohichni nauky: teoriia, istoriia, innovatsini tekhnolohii, 4, 178-185 [in Ukrainian].

2. Vyshcha osvita Ukrainy i Bolonskyi protses (2004). V. H. Kremenia (Ed.). Ternopil: Navchalna knyha. Bohdan [in Ukrainian].

3. Odyntsova, V. M., Roshchupkyna, O. A. (2012). Osoblyvosti navchannia inozemnykh studentiv v umovakh kredytno-modulnoi systemy. Zaporozhskyi medytsynskyi zhurnal [in Ukrainian].

4. Pro provedennia pedahohichnoho eksperymentu z kredytno-modulnoi systemy orhanizatsii navchalnoho protsesu: Nakaz Ministerstva osvity i nauky Ukrainy No 48 vid 23.01.2004. URL: https://zakon. rada.gov.ua/rada/show/v0048290-04\#Text [in Ukrainian].

5. Kurliand, Z. N. (2008). Psykholoho-pedahohichni umovy formuvannia profesiino-pedahohichnoi kompetentnosti maibutnioho vchytelia. Nauka i osvita, 8-9, 171-176 [in Ukrainian].

6. Piankovska, I. V. (2008). Vyznachennia kliuchovykh kompetentnostei maibutnikh uchyteliv u krainakh Yevropy. Vyshcha osvita Ukrainy. Tematychnyi vypusk «Vyshcha osvita Ukrainy u konteksti intehratsii do yevropeiskoho osvitnioho prostoru», Vol. 1, Issue 8, 384-391 [in Ukrainian].

7. Semerikov, S. O. (2009). Fundamentalizatsiia navchannia informatsiinykh dystsyplin u vyshchii shkoli. M. I. Zhaldak (Ed.). Kryvyi Rih: Mineral; K.: NPU im. M. P. Drahomanova [in Ukrainian].

8. Stepko, M. F. (2009). Kompetentnisnyi pidkhid: yoho sutnist. Shcho ye pryiniatnym, a shcho problemnym dlia vyshchoi osvity Ukrainy. Vyshcha osvita Ukrainy: teor. ta naukovo-metod. chasopys. Kyiv, 43-52 [in Ukrainian].

9. Teplytskyi, O. I. (2008). Obiektno-oriientovane modeliuvannia v systemi fundamentalizatsii pidhotovky maibutnioho vchytelia informatyky. Zbirnyk naukovykh prats. Pedahohichni nauky. Kherson: Vyd-vo KHDU. Issue 50, part 2 [in Ukrainian]. 